\title{
Geographic Variation in Informed Consent Law: Two Standards for Disclosure of Treatment Risks
}

\author{
David M. Studdert, Michelle M. Mello, Marin K. Levy, \\ Russell L. Gruen, Edward J. Dunn, E. John Orav, and \\ Troyen A. Brennan*
}

\begin{abstract}
We analyzed 714 jury verdicts in informed consent cases tried in 25 states in 1985-2002 to determine whether the applicable standard of care ("patient" vs. "professional" standard) affected the outcome. Verdicts for plaintiffs were significantly more frequent in states with a patient standard than in states with a professional standard (27 percent vs. 17 percent, $P=0.02$ ). This difference in outcomes did not hold for other types of medical malpractice litigation (36 percent vs. 37 percent, $P=0.8$ ). The multivariate odds of a plaintiff's verdict were more than twice as high in states with a patient standard than in states with a professional standard (odds ratio $=2.15,95 \%$ confidence interval $=1.32-3.50$ ). The law's expectations of clinicians with respect to risk disclosure appear to vary geographically.
\end{abstract}

\footnotetext{
*Address correspondence to David M. Studdert, Melbourne Law School, University of Melbourne, Victoria, Australia; email: d.studdert@unimelb.edu.au. Studdert is Professor and Federation Fellow in the Faculties of Law and Medicine, Dentistry, and Health Sciences at the University of Melbourne. Mello is Associate Professor of Health Policy and Law in that department. Levy is a J.D. candidate at Yale Law School. Gruen is Associate Professor of Surgery in the Faculty of Medicine, Dentistry, and Health Sciences at the University of Melbourne, Australia. Dunn is Director of Policy \& Clinical Affairs, Veterans Affairs National Center for Patient Safety. Orav is an Associate Professor in the Department of Biostatistics at the Harvard School of Public Health. Brennan is Chief Medical Officer of Aetna, Inc.

This work was supported by general institutional funds; Studdert was also supported in part by Grant KO2HS11285 from the Agency for Healthcare Research and Quality. The authors thank Carly Kelly and Tony Yang for legal research assistance, and David Mooney, Amanda Cavicchio, and Doug Smink for assistance with the verdict reviews. Atul Gawande and Alan Meisel provided helpful comments on an earlier draft of the article.
} 


\section{INTRODUCTION}

Every human being of adult years and sound mind has a right to determine what shall be done with his own body; and a surgeon who performs an operation without his patient's consent, commits an assault, for which he is liable in damages. ${ }^{1}$

Beginning in 1914 with Justice Cardozo's now-famous pronouncement in Schloendorff $v$. Society of New York Hospital, the legal doctrine of informed consent has matured through a series of important court decisions. ${ }^{2}$ Early cases alleging failure to obtain consent for medical care were tried as cases of battery-literally, unconsented touching. ${ }^{3}$ Eventually, courts moved toward evaluating informed consent claims using negligence law. ${ }^{4}$ A "professional" standard applied, meaning that the question of whether the defendant's behavior had breached the standard of care was determined by reference to what the defendant's professional peers characterized as reasonable or customary medical practice, drawing informed consent doctrine into line with other forms of medical malpractice litigation. ${ }^{5}$

The most significant development in the law of informed consent during the last 40 years has been a reformulation of the negligence standard in circumstances involving disclosure of treatment risks. ${ }^{6}$ Two 1972 cases, Canterbury v. Spence ${ }^{7}$ and Cobbs v. Grant, ${ }^{8}$ shifted the focus of the inquiry from physician to patient by creating a "lay" or "patient" standard. According to this standard, allegations of failure to disclose are to be judged according to jury assessments of what a reasonable patient in the plaintiff's position would expect to be told prior to making a decision about treatment (patient

${ }^{1}$ Schloendorff v. Society of N.Y. Hosp., 105 N.E. 92, 93 (N.Y. 1914).

${ }^{2}$ Canterbury v. Spence, 464 F.2d 772 (D.C. Cir. 1972); Cobbs v. Grant, 502 P.2d. 1 (Cal. 1972); Natanson v. Kline, 186 Kan. 393 (Kan. 1960); Salgo v. Leland Stanford Jr. Univ. Bd. of Trs., 317 P.2d 170 (Cal. Ct. App. 1957).

${ }^{3}$ Mohr v. Williams, 95 Minn. 261 (Minn. 1905).

${ }^{4}$ Jay Katz, The Silent World of Doctor and Patient 65-69 (2002).

${ }^{5}$ William P. Keeton et al., Prosser \& Keeton on the Law of Torts 189 (5th ed. 1984).

${ }^{6}$ Ruth Faden \& Thomas Beauchamp, A History and Theory of Informed Consent (1986).

${ }^{7} 464$ F.2d at $781-88$.

${ }^{8} 502$ P.2d at $10-12$. 
standard), rather than testimony by medical experts about which risks and alternatives physicians customarily convey (professional standard). "It is the prerogative of the patient, not the physician," Judge Robinson declared in Canterbury, "to determine for himself the direction in which his interests seem to lie."

The Canterbury and Cobbs decisions have spawned an intriguing schism in American health law. In the decades following, superior courts in most states have weighed them, or their progeny, and ruled to accept or reject the departure from conventional malpractice law. Some states underpinned a common-law shift to the patient standard with explicit statutory statements establishing this standard as the correct one in cases involving allegations that material risks of treatment went undisclosed. ${ }^{10}$ Other states have gone in the opposite direction, using statutory affirmations of the professional standard to counteract such judicial innovation. ${ }^{11}$

The upshot is that 25 states and the District of Columbia have embraced the patient standard, while 23 have maintained the professional standard. The laws in the remaining two states, Colorado and Georgia, are not easily classifiable as one or the other. Figure 1 provides a pictorial snapshot. Table 1 identifies the statutes and leading cases that enunciate the applicable standard in each state.

The notoriety and watershed nature of the Canterbury and Cobbs decisions has extended their influence beyond the United States. Appellate courts in Australia, ${ }^{12}$ Malaysia, ${ }^{13}$ New Zealand, ${ }^{14}$ Ireland,${ }^{15}$

\footnotetext{
${ }^{9} 464$ F.2d at 781.
}

${ }^{10}$ Paul C. Weiler, Medical Malpractice on Trial 30 (1991); Alan Meisel \& Lisa D. Kabnick, Informed Consent to Medical Treatment: An Analysis of Recent Legislation, 41 U. Pitt. L. Rev. 407 (1980).

\footnotetext{
${ }^{11}$ This legislative move was particularly evident following tort "crises" in the mid-1970s and mid-1980s when statutory provisions affirming the professional standard were sometimes included in state tort reform packages, presumably because they were regarded by lawmakers as one mechanism among several for reducing the volume and costs of malpractice litigation.

${ }^{12}$ Naxakis v. Western Gen. Hosp. (1999) 73A.L.J.R. 782; Rogers v. Whittaker (1992) 175 C.L.R. 479.

${ }^{13}$ Hong Chuan Lay v. Dr. Eddie Soo Fook Mun (1998) 5 C.L.J. 251; Kamalam v. Eastern Plantation Agency (1996) 4 M.L.J. 674.

${ }^{14}$ B v. Medical Council (High Court, Auckland HC11/1996, 8 July 1996).

${ }^{15}$ Geoghegan v. Harris, [2000] I.R. 536.
} 
Figure 1: Disclosure standards for informed consent in the United States.*

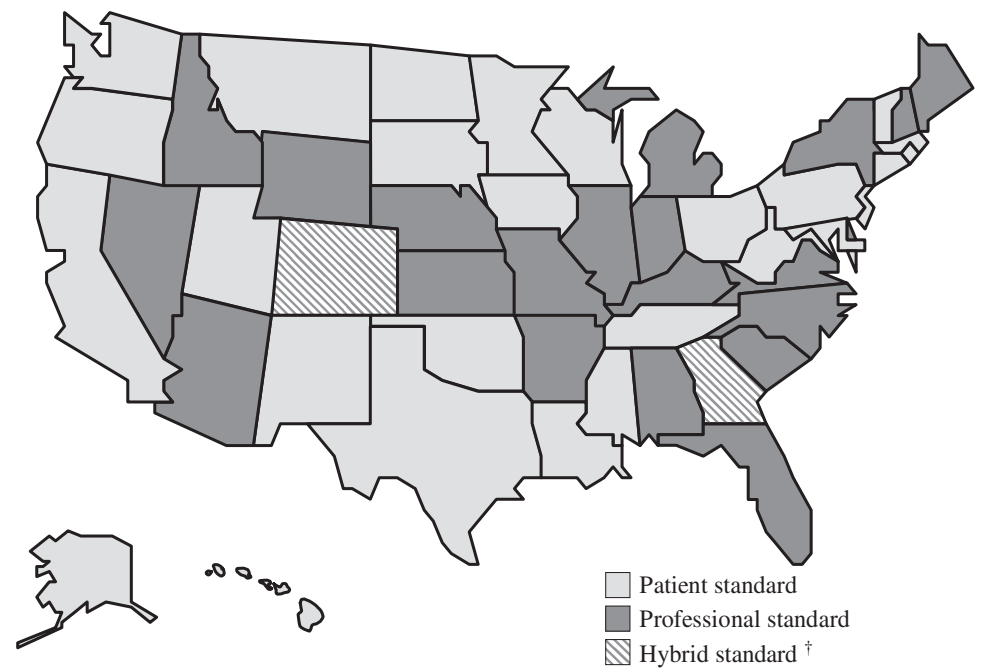

*Depicts laws in place through 2002.

'Colorado and Georgia are classified as "hybrid" because their laws blend aspects of the patient and professional standards, without expressing a clear preference for either.

and Canada ${ }^{16}$ have grappled with the appropriate standard for disclosure of treatment risks, and opted for a patient standard. Courts in Singapore, ${ }^{17}$ on the other hand, have explicitly rejected the patient standard in favor of a professional one. In England, the professional standard has historically governed, ${ }^{18}$ although there have been some recent signs of erosion of this deference to professional opinion in English negligence law. ${ }^{19}$

\footnotetext{
${ }^{16}$ Reibl v. Hughes, [1980] 2 S.C.R. 880.

${ }^{17}$ Jason Carlos Francisco v. Dr. L.M. Thng \& Singapore Gen. Hosp. (Suit No. 573 of 1998, unreported).

${ }^{18}$ Sidaway v. Board of Governors of Bethlehem Royal Hosp., [1985] A.C. 871; Bolam v. Friern Hosp. Mgmt. Comm. (1957) 2 All E.R. 118.

${ }^{19}$ Bolitho v. City \& Hackney Health Auth. (1997) 4 All E.R. 771; Margot Brazier \& Jose Miola, Bye-Bye Bolam: A Medical Litigation Revolution? 8 Med. L. Rev. 85 (2000); General Medical Council, Seeking Patients' Consent: The Ethical Considerations (1998), available at 〈http:// www.gmc-uk.org/standards/consent.htm\#note_2
} 
Table 1: Legal Bases of Disclosure Standards, by State*

\begin{tabular}{|c|c|c|c|}
\hline State & Standard & Statutes & Leading Cases \\
\hline Alabama & Professional & - & $\begin{array}{l}\text { Fain v. Smith, } 470 \text { So. } 2 d \\
1150 \text { (Ala. 1985) }\end{array}$ \\
\hline Alaska & Patient & Alaska Stat. § 09.55.556(a) & $\begin{array}{c}\text { Korman v. Mallin, } 858 \text { P.2d } \\
1145 \text { (Alaska 1993) }\end{array}$ \\
\hline Arizona & Professional & - & $\begin{array}{l}\text { Riedisser v. Nelson, } 534 \text { P.2d } \\
1052 \text { (Ariz. 1975) }\end{array}$ \\
\hline Arkansas & Professional & $\begin{array}{l}\text { Ark. Code Ann. } \\
\quad § 16-114-206\end{array}$ & $\begin{array}{l}\text { Eady v. Lansford, } 92 \text { S.W.3d } \\
57 \text { (Ark. 2002) } \\
\text { Fuller v. Starnes, } 597 \text { S.W.2d } \\
\quad 88 \text { (Ark. 1980) }\end{array}$ \\
\hline California & Patient & - & $\begin{array}{l}\text { Cobbs v. Grant, } 502 \text { P.2d } 1 \\
\quad \text { (Cal. 1972) }\end{array}$ \\
\hline Colorado & Hybrid & - & $\begin{array}{l}\text { Gorab v. Zook, } 943 \text { P.2d } \\
\text { 423, 427-28 (Colo. } \\
\text { 1997) }\end{array}$ \\
\hline Connecticut & Patient & - & $\begin{array}{l}\text { Godwin v. Danbury Eye } \\
\text { Physicians Eै Surgeons, } \\
757 \text { A.2d } 516 \text { (Conn. } \\
\text { 2000) }\end{array}$ \\
\hline D.C. & Patient & - & $\begin{array}{l}\text { Crain v. Allison, } 443 \text { A.2d } \\
558 \text { (D.C. 1982) } \\
\text { Canterbury v. Spence, } 464 \\
\text { F.2d } 772 \text { (D.C. Cir. } \\
\text { 1972) }\end{array}$ \\
\hline Delaware & Professional & $\begin{array}{l}\text { Del. Code Ann. tit. 18, } \\
\quad § 6852\end{array}$ & $\begin{array}{l}\text { DiFilippo v. Preston, } 173 \\
\quad \text { A.2d } 333 \text { (Del. 1961) }\end{array}$ \\
\hline Florida & Professional & - & $\begin{array}{l}\text { Ditlow v. Kaplan, } 181 \text { So. } \\
\text { 2d } 226 \text { (Fla. App. 1966) }\end{array}$ \\
\hline Georgia & Hybrid & Ga. Code Ann. $§ 31-9-6.1$ & $\begin{array}{l}\text { Albany Urology Clinic. } v . \\
\text { Cleveland, } 528 \text { S.E.2d } 777 \\
\text { (Ga. 2000) }\end{array}$ \\
\hline Hawaii & Patient & Haw. Rev. Stat. $§ 671-3$ & $\begin{array}{l}\text { Carr v. Strode, } 904 \text { P.2d } 489 \\
\quad \text { (Haw. 1995) }\end{array}$ \\
\hline Idaho & Professional & $\begin{array}{l}\text { Idaho Code Ann. } \\
\quad \S 39-4304\end{array}$ & $\begin{array}{l}\text { Sherwood v. Carter, } 805 \text { P.2d } \\
452 \text { (Idaho 1991) }\end{array}$ \\
\hline Illinois & Professional & - & $\begin{array}{l}\text { Weekly v. Solomon, } 510 \\
\text { N.E.2d } 152 \text { (Ill.App. } 2 \\
\text { Dist. 1987) }\end{array}$ \\
\hline Indiana & Professional & Ind. Code $\S 16-36-1.5-7$ & $\begin{array}{r}\text { Culbertson v. Mernitz, } 602 \\
\text { N.E.2d } 98 \text { (Ind. 1992) }\end{array}$ \\
\hline Iowa & Patient & - & $\begin{array}{l}\text { Pauscher v. Iowa Methodist } \\
\text { Med. Ctr., } 408 \text { N.W.2d } \\
355 \text { (Iowa 1987) }\end{array}$ \\
\hline Kansas & Professional & - & $\begin{array}{l}\text { Natanson v. Kline, } 350 \text { P.2d } \\
1093 \text { (Kan. 1960) }\end{array}$ \\
\hline
\end{tabular}


Table 1. Continued

\begin{tabular}{|c|c|c|c|}
\hline State & Standard & Statutes & Leading Cases \\
\hline Kentucky & Professional & $\begin{array}{l}\text { Ky. Rev. Stat. Ann. } \\
\$ 304.40-320\end{array}$ & $\begin{array}{l}\text { Holton v. Pfingst, } 534 \\
\quad \text { S.W.2d } 786 \text { (Ky. 1976) }\end{array}$ \\
\hline Louisiana & Patient & $\begin{array}{l}\text { La. Rev. Stat. Ann. } \\
\$ 40: 1299.40\end{array}$ & $\begin{array}{l}\text { Hondroulis v. Schuhmacher, } \\
553 \text { So. 2d } 398 \text { (La. } \\
\text { 1988) }\end{array}$ \\
\hline Maine & Professional & $\begin{array}{l}\text { Me. Rev. Stat. Ann. tit. } 24 \\
\text { § } 2905\end{array}$ & $\begin{array}{r}\text { Woolley v. Henderson, } 418 \\
\text { A.2d } 1123(\text { Me. 1980) }\end{array}$ \\
\hline Maryland & Patient & - & $\begin{array}{l}\text { Sard v. Hardy, } 379 \text { A.2d } \\
1014(\mathrm{Md} .1977)\end{array}$ \\
\hline Massachusetts & Patient & - & $\begin{array}{l}\text { Harnish v. Children's Hosp. } \\
\text { Med. Ctr., } 439 \text { N.E.2d } \\
240 \text { (Mass. 1982) }\end{array}$ \\
\hline Michigan & Professional & - & $\begin{array}{l}\text { Roberts v. Young, } 119 \\
\text { N.W.2d } 627 \text { (Mich. } \\
\text { 1963) }\end{array}$ \\
\hline Minnesota & Patient & - & $\begin{array}{l}\text { Cornfeldt v. Tongen, } 295 \\
\text { N.W.2d } 638 \text { (Minn. } \\
\text { 1980) }\end{array}$ \\
\hline Mississippi & Patient & - & $\begin{array}{l}\text { Reikes v. Martin, } 471 \text { So. 2d } \\
\quad 385 \text { (Miss. 1985) }\end{array}$ \\
\hline Missouri & Professional & - & $\begin{array}{l}\text { Aiken v. Clary, } 396 \text { S.W.2d } \\
668 \text { (Mo. 1965) }\end{array}$ \\
\hline Montana & Professional & - & $\begin{array}{l}\text { Negaard v. Feda's Estate, } 446 \\
\text { P.2d } 436 \text { (Mont. 1968) }\end{array}$ \\
\hline Nebraska & Professional & Neb. Rev. Stat. § 44-2816 & $\begin{array}{l}\text { Smith v. Weaver, } 407 \\
\quad \text { N.W.2d } 174 \text { (Neb. 1987) }\end{array}$ \\
\hline Nevada & Professional & Nev. Rev. Stat. $§ 449.710$ & $\begin{array}{c}\text { Smith v. Cotter, } 810 \text { P.2d } \\
1204 \text { (Nev. 1991) }\end{array}$ \\
\hline $\begin{array}{l}\text { New } \\
\text { Hampshire }\end{array}$ & Professional & - & $\begin{array}{l}\text { Folger v. Corbett, } 394 \text { A.2d } \\
\quad 63 \text { (N.H. 1978) }\end{array}$ \\
\hline New Jersey & Patient & - & $\begin{array}{l}\text { Largey v. Rothman, } 540 \\
\text { A.2d } 504 \text { (N.J. 1988) }\end{array}$ \\
\hline $\begin{array}{l}\text { New } \\
\text { Mexico }\end{array}$ & Patient & - & $\begin{array}{c}\text { Gerety v. Demers, } 589 \text { P.2d } \\
180 \text { (N.M. 1978) }\end{array}$ \\
\hline New York & Professional & $\begin{array}{l}\text { N.Y. Pub. Health Law } \\
\quad \S 2805-\mathrm{d}\end{array}$ & $\begin{array}{l}\text { Troy v. Long Island } \\
\text { Jewish-Hillside Med. Ctr., } \\
446 \text { N.Y.S.2d } 347 \text { (N.Y. } \\
\text { App. Div. 1982) }\end{array}$ \\
\hline $\begin{array}{l}\text { North } \\
\text { Carolina }\end{array}$ & Professional & N.C. Gen. Stat. $§ 90-21.13$ & $\begin{array}{l}\text { Foard v. Jarman, } 387 \text { S.E.2d } \\
\quad 162 \text { (N.C. 1990) }\end{array}$ \\
\hline $\begin{array}{l}\text { North } \\
\text { Dakota }\end{array}$ & Patient & - & $\begin{array}{l}\text { Jaskoviak v. Gruver, } 638 \\
\text { N.W.2d } 1 \text { (N.D. 2002) }\end{array}$ \\
\hline Ohio & Patient & - & $\begin{array}{l}\text { Nickell v. Gonzalez, } 477 \\
\text { N.E.2d } 1145 \text { (Ohio } \\
\text { 1985) }\end{array}$ \\
\hline
\end{tabular}


Table 1. Continued

\begin{tabular}{|c|c|c|c|}
\hline State & Standard & Statutes & Leading Cases \\
\hline Oklahoma & Patient & - & $\begin{array}{l}\text { Scott v. Bradford, } 606 \text { P.2d } \\
554 \text { (Okla. 1980) }\end{array}$ \\
\hline Oregon & Patient & Or. Rev. Stat. $\$ 677.097$ & $\begin{array}{l}\text { Macy v. Blatchford, } 8 \text { P.3d } \\
204 \text { (Or. 2000) }\end{array}$ \\
\hline Pennsylvania & Patient & $\begin{array}{l}40 \text { Pa. Cons. Stat. } \\
\$ 1303.504\end{array}$ & $\begin{array}{l}\text { Sinclair by Sinclair v. Block, } \\
633 \text { A.2d } 1137 \text { (Pa. } \\
\text { 1993) }\end{array}$ \\
\hline $\begin{array}{l}\text { Rhode } \\
\text { Island }\end{array}$ & Patient & - & $\begin{array}{c}\text { Wilkinson v. Vesey, } 295 \text { A.2d } \\
\text { 676, } 689 \text { (R.I. 1972) }\end{array}$ \\
\hline $\begin{array}{l}\text { South } \\
\text { Carolina }\end{array}$ & Professional & - & $\begin{array}{l}\text { Hook v. Rothstein, } 316 \\
\text { S.E.2d 690, } 698 \text { (S.C. } \\
\text { App. 1984) }\end{array}$ \\
\hline $\begin{array}{l}\text { South } \\
\text { Dakota }\end{array}$ & Patient & - & $\begin{array}{l}\text { Wheeldon v. Madison, } 374 \\
\text { N.W.2d } 367 \text { (S.D. 1985) }\end{array}$ \\
\hline Tennessee & Patient & $\begin{array}{l}\text { Tenn. Code Ann. } \\
\qquad \begin{array}{c}\text { 29-26-118 }\end{array}\end{array}$ & $\begin{array}{l}\text { Ashe v. Radiation Oncology } \\
\text { Assoc., } 9 \text { S.W.3d } 119 \\
\text { (Tenn. 1999) }\end{array}$ \\
\hline Texas & Patient & $\begin{array}{l}\text { Tex. Rev. Civ. Stat. Ann. } \\
\text { art. } 4590 \mathrm{i}, \S 6.02\end{array}$ & $\begin{array}{l}\text { Peterson v. Shields, } 652 \\
\text { S.W.2d } 929 \text { (Tex. 1983) }\end{array}$ \\
\hline Utah & Patient & Utah Code Ann. $\$ 78-14-5$ & $\begin{array}{l}\text { Nixdorf v. Hicken, } 612 \text { P.2d } \\
\quad 348 \text { (Utah 1980) }\end{array}$ \\
\hline Vermont & Patient & $\begin{array}{l}\text { Vt. Stat. Ann. tit. 12, } \\
\quad \$ 1909\end{array}$ & $\begin{array}{l}\text { Small v. Gifford Mem'l } \\
\text { Hosp., } 349 \text { A.2d } 703 \text { (Vt. } \\
\text { 1975) }\end{array}$ \\
\hline Virginia & Professional & - & $\begin{array}{l}\text { Rizzo v. Schiller, } 445 \text { S.E.2d } \\
153 \text { (Va. 1994) }\end{array}$ \\
\hline Washington & Patient & $\begin{array}{l}\text { Wash. Rev. Code Ann. } \\
\quad \$ 7.70 .050\end{array}$ & $\begin{array}{l}\text { Miller v. Kennedy, } 522 \text { P.2d } \\
\text { 852, } 860 \text { (Wash. App. } \\
\text { 1974) }\end{array}$ \\
\hline $\begin{array}{l}\text { West } \\
\text { Virginia }\end{array}$ & Patient & - & $\begin{array}{c}\text { Cross v. Trapp, } 294 \text { S.E.2d } \\
\text { 446, } 455 \text { (W.Va. 1982) }\end{array}$ \\
\hline Wisconsin & Patient & Wis. Stat. Ann. $§ 448.30$ & $\begin{array}{l}\text { Martin by Scoptur v. } \\
\quad \text { Richards, } 531 \text { N.W.2d } 70 \\
\text { (Wis. 1995) }\end{array}$ \\
\hline Wyoming & Professional & - & $\begin{array}{l}\text { Roybal v. Bell, } 778 \text { P.2d } \\
\text { 108, } 112 \text { (Wyo. 1989) }\end{array}$ \\
\hline
\end{tabular}

*Summarizes laws in place through 2002.

Patient standards for disclosure have been lauded as progressive from a patients' rights perspective, but little is known about their impact. We analyzed a sample of informed consent verdicts across multiple U.S. jurisdictions to test whether the type of legal standard applied affected outcomes of litigation. Our hypothesis was that plaintiffs would tend to fare better when their cases were decided under a patient standard. 


\section{Methods}

\section{A. Data and Sample}

Our data came from case summaries compiled by 16 jury verdict publishers covering 29 states and the District of Columbia. The publishers, which produce the California Jury Verdicts Weekly, the Florida Jury Verdict Reporter, and the Northwest Personal Injury Litigation Reports, are private companies that specialize in summarizing state court decisions in all types of civil litigation. ${ }^{20}$ The publishers use a variety of approaches to identify decisions, including periodic reviews of court dockets, surveys of attorneys involved in the litigation, voluntary reports from involved attorneys, and news and wire reports. Each publisher then uses a standard template to record details of the decisions. Case details are obtained primarily through attorney surveys, although some publishers also collect information through direct observation of trials. Before finalizing reports, publishers attempt to verify their accuracy by circulating draft reports to attorneys involved in the case. The reports are used widely by attorneys and insurers for case evaluation and litigation strategy, and have been used in previous studies of litigation. ${ }^{21}$

Lexis-Nexis catalogues the case reports electronically. We searched for verdicts from the period 1985 through 2002 that included the term "informed consent." The search yielded 2,783 reports, 1,614 of which were from California. We limited California's contribution to 200 verdicts selected at random; for the other states, we sampled all verdicts from the study time period.

Two investigators then reviewed the sampled verdicts one by one $(N=1,369)$. We eliminated duplicates (214); cases in which informed consent was mentioned but there was no allegation of a breach (326); cases in which the jury's decision could not be linked to the informed consent allegation due to the confounding effect of an accompanying allegation of negligent treatment (100); 11 verdict dates outside the study range; and four

\footnotetext{
${ }^{20}$ National Association of State Jury Verdict Publishers, Jury Verdict Summaries (2002), available at $\langle$ http://www.juryverdicts.com〉.

${ }^{21}$ See, e.g., Michael G. Shanley \& Mark A. Peterson, RAND, Comparative Justice: Civil Jury Verdicts in San Francisco and Cook Counties, 1959-1980 (1982); Samuel R. Gross \& Kent D. Syverud, Getting to "No": A Study of Settlement Negotiations and the Selection of Cases for Trial, 90 Mich. L. Rev. 319 (1991); Neil Vidmar et al., Jury Awards for Medical Malpractice and Post-Verdict Adjustments of Those Awards, 48 DePaul L. Rev. 265 (1998).
} 
cases that resulted in hung juries. This process of elimination left 714 verdicts from 25 states (AZ, AK, CA, CT, FL, IL, IN, KY, LA, ME, MD, MA, MI, MO, NH, NJ, NY, OH, PA, RI, TX, VT, VA, WA, WI).

\section{B. Verdict Review}

For each case, we documented the plaintiff's sex and age, the defendant's specialty, the party in whose favor the case was decided, and the dollar value of the verdict (if any). We also flagged cases in which the verdict report indicated that there was a factual dispute about whether the risk at issue had been disclosed; in other words, situations in which defendants insisted that the risk at issue had been disclosed (as opposed to the argument that there was no obligation to disclose this risk).

Next, the subset of cases that alleged failure to disclose risks of surgery were divided among four surgeons (one board-certified cardiothoracic surgeon, one board-certified pediatric surgeon, and two surgical fellows) who independently reviewed them using an instrument designed for this purpose. The reviewers recorded the index procedure, defined as the procedure most directly responsible for the adverse outcome(s) alleged by the plaintiff, and the index adverse outcome, defined as the most serious harm alleged by the plaintiff to be causally related to the index procedure.

Next, the reviewers scored the severity of the index adverse outcome using the National Association of Insurance Commissioners' severity-ofinjury scale. ${ }^{22}$ This nine-point scale ranges from emotional injury only (score of 1) to death (score of 9). Finally, the reviewers estimated the risk that the index procedure would give rise to the index adverse outcome. Risk judgments were made on a six-point nonlinear scale with the following values: 1 in 10; 1 in 50; 1 in 100; 1 in 500; 1 in 1,000; and 1 in 5,000. Reviewers chose the probability that came closest to their determination of the risk involved and were instructed to consult relevant literature if they were unfamiliar with particular risks arising in the cases.

To test the reliability of the surgical review, we submitted 65 randomly selected verdicts (about 12 percent of the sample) to independent review by a second surgeon (one of the original four) who was blinded to the fact that the verdict was a rereview. When these pairs of reviews were compared, injury severity scores showed very good agreement: 48 (74 percent) of the reviews

\footnotetext{
${ }^{22}$ National Association of Insurance Commissioners, Malpractice Claims: Final Compilation (M. Patricia Sowka ed., 1980).
} 
were concordant and 10 (15 percent) differed by one severity level (weighted kappa $=0.68)$. Agreement on the risk scores was fair: the vast majority were concordant (42 percent) or differed by one risk level (42 percent), but eight (12 percent) differed by two risk levels and three ( 5 percent) by three risk levels (weighted kappa $=0.28$ ). After concluding the reliability testing, the investigators discussed disagreements with the reviewers to reach consensus.

\section{Control for the General Malpractice Litigation Environment}

We generated a variable to control for aspects of a state's legal environment, other than the informed consent standard, that might affect plaintiffs' chances of prevailing in a medical malpractice case. For each of the 25 states represented in the study sample, we drew from the Lexis-Nexis database an additional sample of medical malpractice verdicts decided between 1985 and 2002 that did not involve issues of informed consent. We randomly sampled of 100 verdicts from each of 12 states. The remaining 13 states had fewer than 100 available verdicts, so we sampled all available (range of 2-33, mean $=17$ ). We then calculated a simple plaintiff win rate by state, which was the proportion of malpractice verdicts decided for the plaintiff.

\section{State Law Review}

We undertook a 50-state review of state statutes and controlling court decisions concerning the applicable legal standard for informed consent cases. (The results appear in Figure 1 and Table 1). The review was conducted in early 2003, and summarizes the laws in place through 2002 to match the time period from which verdicts came. It is possible that some changes to informed consent law have occurred since this time. ${ }^{23}$

\section{E. Statistical Analysis}

Our analyses focused on verdicts that involved allegations of failure to disclose surgical risks, both because it was feasible to assign measures of risk to this class of cases and because they constituted the vast majority of informed consent verdicts. We generated descriptive statistics, with verdicts grouped according to whether they came from states with a patient or professional

\footnotetext{
${ }^{23} \mathrm{We}$ are aware of one such change. The Texas Medical Liability and Insurance Improvement Act, enacted in 2003, contained informed consent reforms that may be construed as shifting Texas over to a professional standard (see Acts 2003, 78th Leg., ch. 204, § 10.01, eff. Sept. 1, 2003).
} 
standard. The severity-of-injury scores were collapsed into three levels: minor (emotional only, temporary-minor, temporary-significant); significant (temporary-major, permanent-minor, permanent-significant); and major (major-permanent, grave, death). To account for the differences in the timing of verdicts, we converted the dollar values of awards to 2002 dollars using the Consumer Price Index. ${ }^{24}$

We plotted the mean proportion of plaintiff wins within each state, and then compared overall means from the two types of jurisdictions. The same plots and jurisdictional comparisons were done for the malpractice cases not involving informed consent. Seven states with professional standards (AZ, IL, IN, KY, ME, NH, VA) and three states with patient standards (AK, LA, RI) contributed five or fewer informed consent verdicts to the sample. To avoid instability in our estimates, we clustered them and calculated a single mean for each cluster.

Finally, we tested the relationship between the informed consent standard and case outcomes using multivariate logistic regression. The dependent variable was the prevailing party (plaintiff or defendant). The independent variables were the applicable standard (professional or patient), the risk rating, the injury severity, the plaintiff's gender, the plaintiff's age, a binary variable indicating whether there was a factual dispute about the disclosure, verdict year, and the state-specific patient win rate for medical malpractice litigation unrelated to informed consent.

The regression analysis was weighted to allow each state to contribute equal explanatory power, regardless of the actual number of verdicts it had in the sample. The two clusters of low-count states described above were weighted as if they were single states. All analyses were conducted using the Stata/SE 8.0 statistical software package (Stata Corp., College Station, TX).

\section{Results}

Eighty-eight percent of informed consent verdicts related to surgical procedures (Table 2). The dominant allegation in these cases was that the surgeon failed to warn the patient of pertinent risks (89 percent). Among cases that did not involve surgery, failure to disclose risks was also the most common

\footnotetext{
${ }^{24}$ U.S. Department of Labor, Bureau of Labor Statistics, Inflation Calculator, available at 〈http://data.bls.gov/cgi-bin/cpicalc.pl〉.
} 
Table 2: Types of Informed Consent Verdicts

\begin{tabular}{|c|c|c|c|c|c|}
\hline & $\mathrm{N}$ & $\% *$ & & $\mathrm{~N}$ & $\% *$ \\
\hline Surgical Treatment & 627 & 88 & Nonsurgical Treatment $t^{\dagger}$ & 87 & 12 \\
\hline Allegation of failure to disclose & & & Allegation of failure to disclose & & \\
\hline - Risks of treatment & 555 & 89 & - Risks of treatment & 46 & 53 \\
\hline -Alternative treatment & 58 & 9 & -Alternative treatment & 11 & 13 \\
\hline -Identity of treating clinician ${ }^{\ddagger}$ & 6 & 1 & $\begin{array}{l}\text { Allegation of absolute failure to } \\
\text { obtain consent for a treatment }\end{array}$ & 11 & 13 \\
\hline $\begin{array}{l}\text { —Clinician's } \\
\text { experience/expertise }\end{array}$ & 6 & 1 & Other & 8 & 9 \\
\hline Other & 2 & 0.3 & & & \\
\hline
\end{tabular}

*Percentages for treatment categories are calculated from all cases in the sample $(N=714)$; allegation subcategories are calculated within surgical $(N=627)$ and nonsurgical categories $(N=87)$, respectively.

${ }^{\dagger}$ For 11 nonsurgical cases, the nature of the allegation was not evident.

${ }^{\ddagger}$ Allegation that consent was given for treatment by physician A, and physician B actually delivered the treatment.

allegation (53 percent); in most cases the risks pertained to drug side effects (39 percent of nonsurgical cases). Only 11 cases, all of them nonsurgical in nature, dealt with allegations of outright failure to obtain consent for treatment.

Table 3 shows characteristics of the 555 surgical cases involving risk disclosure. Plaintiffs won 24 percent of them, receiving a mean award of approximately $\$ 1.2$ million. One-quarter of cases involved minor harm; the rest alleged significant (71 percent) or major (6 percent) injury. Defendants came from a wide range of surgical specialties, most frequently orthopedic (20 percent), general (16 percent), and plastic/reconstructive (16 percent). The procedures involved were also diverse; the most common were tooth extraction ( 9 percent), foot surgery ( 7 percent), breast surgery ( 6 percent), spinal surgery (6 percent), and hysterectomy/sterilization (6 percent). The mean risk rating of 3.6 corresponds on the six-point scale we used to a probability of between 1 in 100 (score of 3) and 1 in 500 (score of 4) of the adverse outcome occurring as a result of the index procedure.

There were no statistically significant differences across the two types of jurisdictions, with two exceptions. First, plaintiffs in states with a patient standard were slightly younger than their counterparts in states with a professional standard (42 vs. 45 years, $P=0.02$ ). Second, verdicts in favor of plaintiffs were significantly more common in states with a patient standard in 


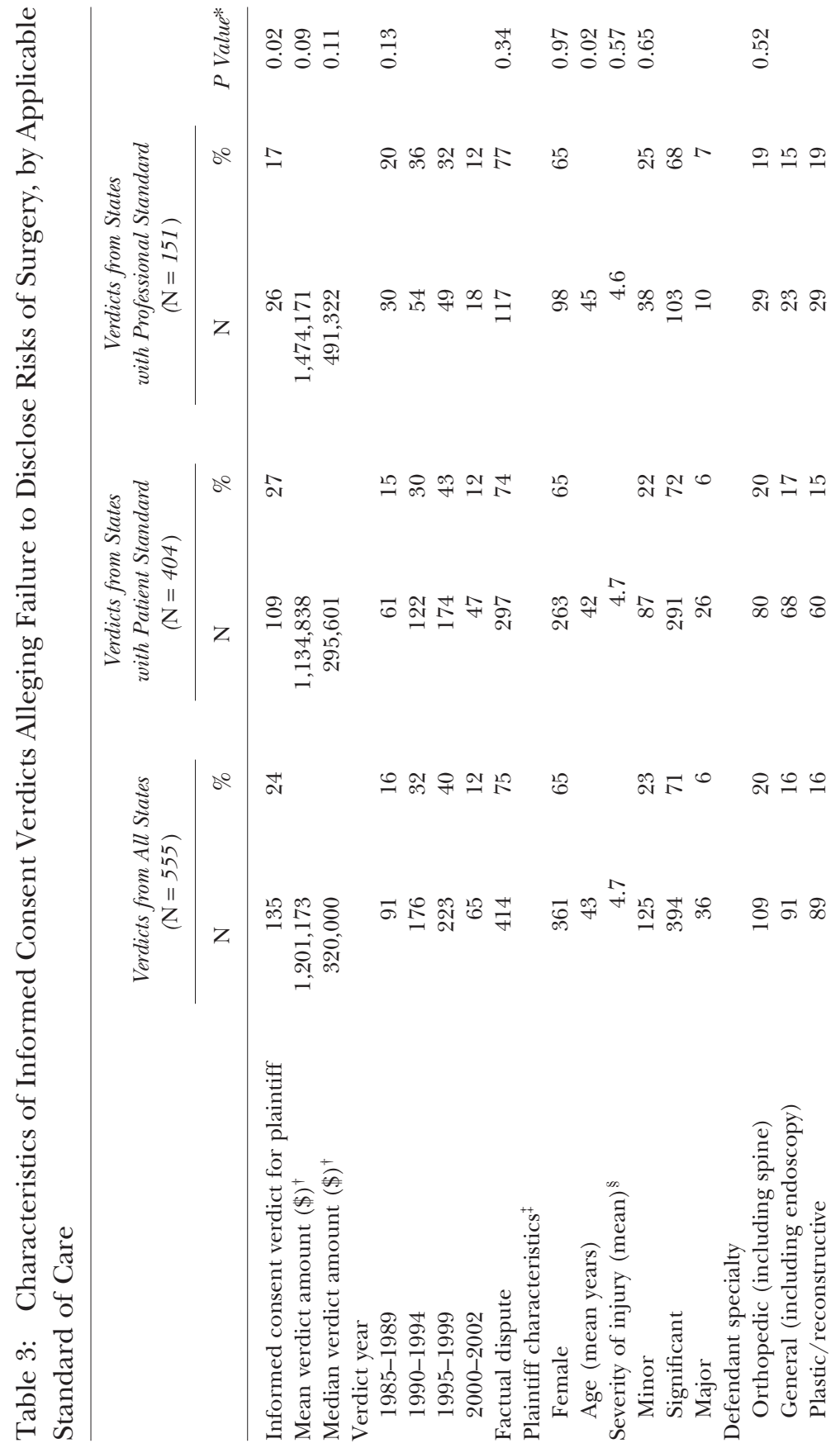




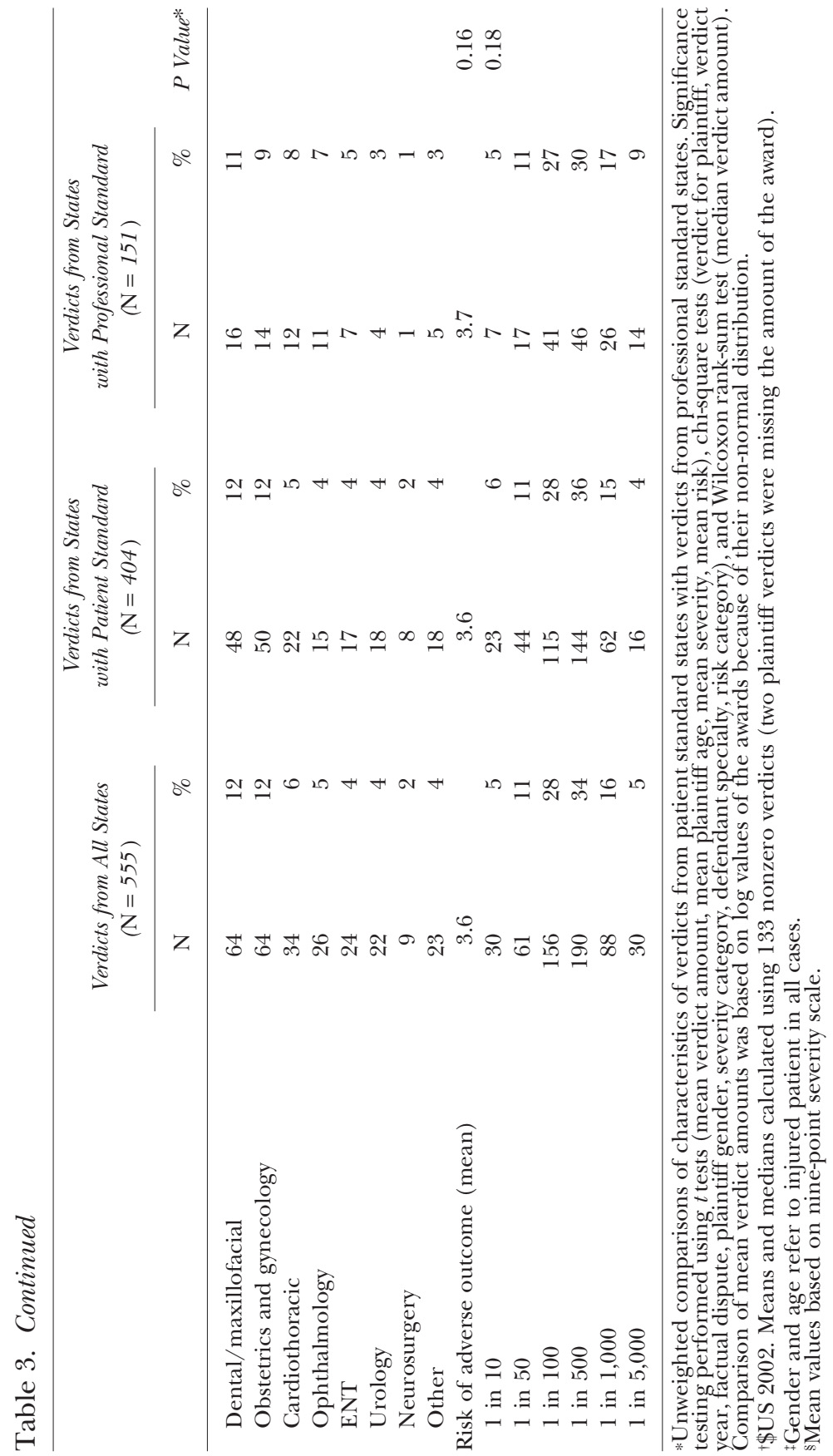


force than in states with a professional standard (27 percent vs. 17 percent, $P=0.02) .{ }^{25}$ One other variable, verdict amounts, trended toward a significant difference between the two groups of states. However, the difference was not significant at the $P<0.05$ level and further testing of the equality of the two distributions using a Kolmogorov-Smirnov test also showed no significant difference $(P=0.39)$.

Figure 2 shows the proportion of verdicts for the plaintiff by state and type of jurisdiction. The left half of the figure makes the jurisdictional comparison among informed consent verdicts; the right half compares other malpractice litigation from the same states. The difference observed in outcomes of informed consent cases by jurisdiction (27 percent vs. 17 percent, $P=0.02$ ) did not hold for other types of medical malpractice litigation (36 percent vs. 37 percent, $P=0.8$ ).

Figure 2 also shows that, overall, informed consent verdicts were less likely than other malpractice cases to result in plaintiff wins (24 percent vs. 36 percent, $P<0.001$ ), a difference observed in every state except Washington. The proportion of informed consent verdicts that went for the plaintiff ranged from none in Missouri (out of 10 cases) to 51 percent in New Jersey (out of 43 cases). Among malpractice verdicts unrelated to informed consent, plaintiffs wins ranged from 26 percent in Massachusetts to 53 percent in Florida.

The unadjusted odds of a verdict in the plaintiff's favor were more than twice as high in states with a patient standard than in states with a professional standard (odds ratio $(\mathrm{OR})=2.58,95 \%$ confidence interval $(\mathrm{CI})=1.62-4.09)$. The higher odds of a patient win observed in bivariate analysis and state-by-state plots were confirmed in multivariate analysis $(\mathrm{OR}=2.15,95 \% \mathrm{CI}=1.32-3.50) \quad($ Table 4$)$. Multivariate analysis also showed that the odds of a plaintiff win decreased approximately 25 percent with each unit increase in the remoteness of the risk on the sixpoint scale.

\footnotetext{
${ }^{25} \mathrm{We}$ also tested for subgroup differences by comparing the plaintiff win rates across the two groups of states within the following strata: verdict year, factual dispute, plaintiff gender, plaintiff age, severity of injury, defendant specialty, risk of adverse outcome. The higher proportion of plaintiff wins in patient standard states did not appear to be an effect localized in one or a few of these variables. It was a fairly homogenous effect, although small sample sizes did not support statistically significant differences in most of the comparisons.
} 
118 Studdert et al.

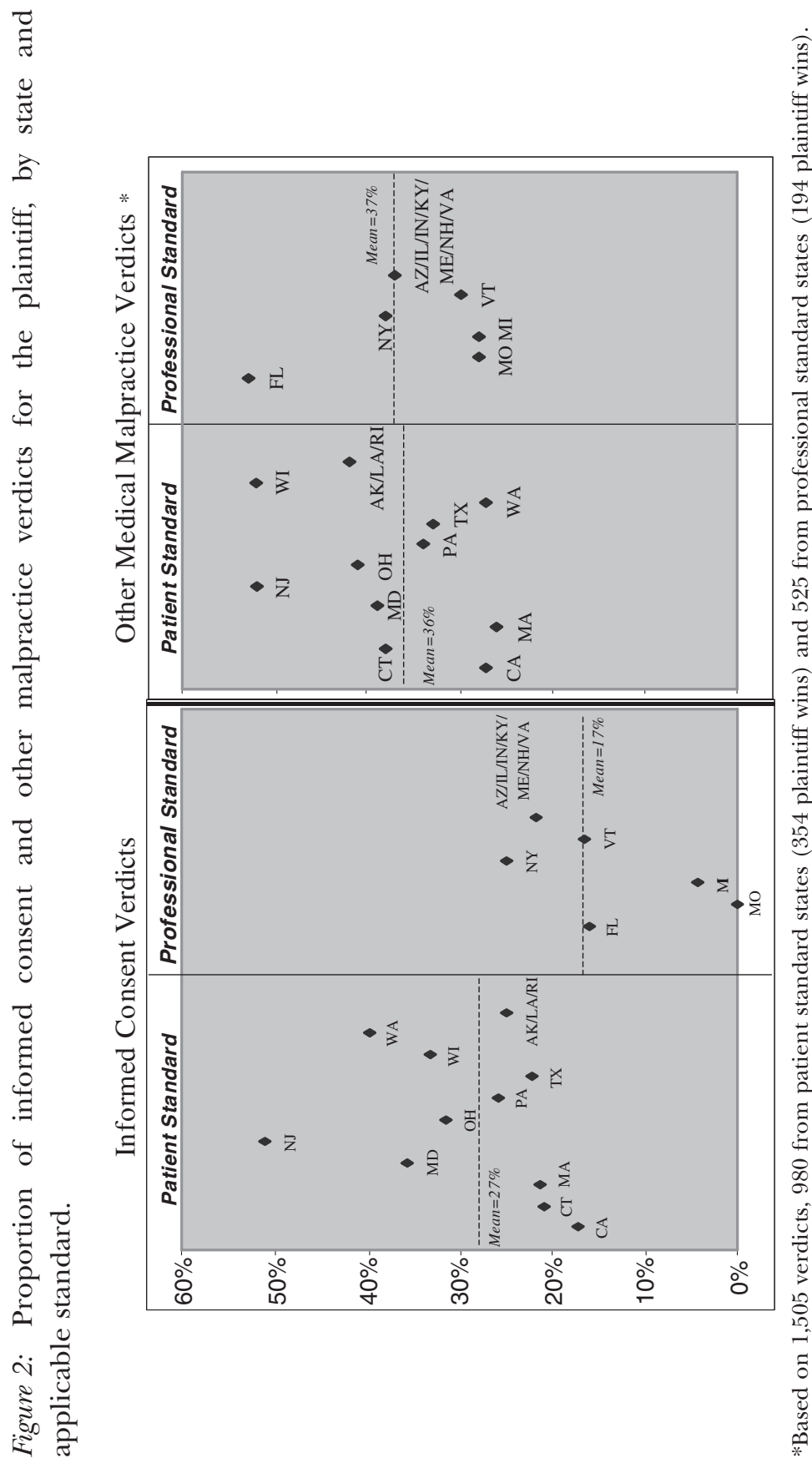


Table 4: Multivariate Odds of Verdict for Plaintiff in Informed Consent Litigation*

\begin{tabular}{|c|c|c|}
\hline Characteristics & Odds of Plaintiff Verdict & $95 \%$ Confidence Interval \\
\hline $\begin{array}{l}\text { Patient standard } \\
\text { jurisdiction }\end{array}$ & $2.15^{\dagger}$ & $1.32-3.50$ \\
\hline Risk of adverse outcome $e^{\ddagger}$ & $0.74^{\dagger}$ & $0.63-0.88$ \\
\hline Severity category ${ }^{\S}$ & 1.02 & $0.68-1.55$ \\
\hline Female & 1.11 & $0.72-1.74$ \\
\hline Age $^{\mathbb{I}}$ & 0.96 & $0.85-1.09$ \\
\hline Factual dispute & $0.56^{\dagger}$ & $0.36-0.86$ \\
\hline Year of verdict & 1.02 & $0.97-1.08$ \\
\hline Other malpractice win** & 1.34 & $1.06-1.69$ \\
\hline
\end{tabular}

*Model weighted by state.

${ }^{\dagger} P<0.01$.

${ }^{\ddagger}$ Six-point scale ranging from probabilities of 1 in 10 (1) to 1 in 5,000 (6).

$\$$ Three-point scale comprising minor (1), significant (2), and major (3) injury.

"Age in 10-year increments.

** Odds ratio relates to 10 percent increase in the odds of plaintiff win.

\section{Discussion}

Absolute failure to obtain patient consent prior to treatment is an aberrant event. Allegations in informed consent litigation typically center on whether the consent given was "informed" and, in particular, on the extent to which risks of treatment were adequately disclosed. ${ }^{26}$ Our study strongly suggests that complaints about undisclosed risks in surgery account for the lion's share of modern informed consent litigation.

Over the last 30 years, courts have wrestled with the question of how to define clinicians' legal obligations relating to disclosure of treatment risks. Two distinct camps have emerged. The traditional position is that alleged breaches of informed consent should, in keeping with the approach taken with other claims of medical negligence, be evaluated according to standards of customary practice espoused by the profession. ${ }^{27}$ The alternative position is that disclosure obligations should be derived through identification of the kinds of risks that reasonable patients would regard as "material" to their

\footnotetext{
${ }^{26}$ Jessica W. Berg et al., Informed Consent: Legal Theory and Clinical Practice 55-58 (2d ed. 2001).

${ }^{27}$ Keeton et al., supra note 5, at 189, 193-95.
} 
decisions about treatment-an inquiry that reposes discretion in judges and juries rather than relying primarily on the testimony of members of the medical profession. Since the first statement of the patient standard was articulated by the Court of Appeals for the District of Columbia in Canterbury v. Spence, courts throughout the United States and in at least seven other countries and have considered the merits of this alternative formulation.

Some commentators hailed the Canterbury decision as a consummating moment in the patients' rights movement; ${ }^{28}$ others criticized it for not going far enough in recognizing patient autonomy. ${ }^{29}$ Critics in the medical community predicted that the shift would lead to amorphous standards and burgeoning litigation. ${ }^{30}$ Implicit in all these reactions, as well as many of the judicial considerations that followed, is that a shift to the patient standard saddles clinicians with greater legal responsibilities around disclosure of risks; in other words, it favors plaintiffs. This study tested that assumption.

Our analysis of informed consent verdicts from 25 states-13 with patient standards in place and 12 with professional standards-found that when the verdicts were grouped according to the two types of jurisdictions, the groups were similar in virtually every respect except the odds of a verdict in the plaintiff's favor, which were more than twice as high in states with patient standards. Overall, plaintiffs' injuries were generally quite serious and payouts were large, averaging more than $\$ 1$ million per compensated case.

What are the main implications of this difference? We note three. First, the split in disclosure standards cannot be dismissed as a matter of legal semantics: the choice of standard influences outcomes of litigation. Moving to a patient standard means that physician defendants incur greater exposure to liability for negligence. Legislators in some states have assumed this connection, and intervened to establish a professional standard through statute as one method for controlling malpractice litigation. ${ }^{31}$

\footnotetext{
${ }^{28}$ Leanna W. Darvall, Medicine, Law and Social Change: The Impact of Bioethics, Feminism, and Rights Movements on Medical Decision-Making (1993); Joan H. Krause, Reconceptualizing Informed Consent in an Era of Health Care Cost Containment, 85 Iowa L. Rev. 261 (1999).

${ }^{29}$ Jay Katz, Informed Consent-A Fairy Tale? Law's Vision, 39 U. Pitt. L. Rev. 137 (1977); Alexander M. Capron, Informed Consent in Catastrophic Disease Research and Treatment, 123 U. Penn. L. Rev. 341 (1974).

${ }^{30}$ Eugene G. Laforet, The Fiction of Informed Consent, 235 JAMA 1579 (1976).

${ }^{31}$ Weiler, supra note 10 , at 30 .
} 
Second, our findings imply that informed consent cases with very similar clinical facts may be decided differently depending on the state in which they are brought. Attorneys will not balk at this type of discrepancy; it is a predictable and accepted product of a federalist legal system. Many physicians, on the other hand, would take a different view. Developments in communication, medical education and training, and specialty colleges over the past 50 years have shifted medicine toward national standards of clinical practice. $^{32}$ Geographic variation in what constitutes acceptable disclosure cuts against the grain of such standardization in medicine. It may also send mixed messages to physicians about the standards they should adhere to in advising patients of treatment risks.

Third, given the crux of the distinction between the two standards, our findings hint at a substantive discrepancy between customary medical practice regarding disclosure of risks (as enunciated through the professional standard of care) and patients' expectations about risk disclosure (as articulated through the patient standard). Previous studies ${ }^{33}$ have identified misalignment between patient and physician preferences for treatment, which is explained as a function of divergent utilities and risk tolerance. It stands to reason that such differences would also emerge from the application of legal standards that cleave to the perceptions of one party or the other. An important caveat to this conclusion is that evidence of the discrepancy observed in this study is refracted through the legal process, which provides only an approximation of what physicians do and patients want, and does so in the context of adverse patient outcomes. If, for instance, under the patient standard, juries' ex post estimations of patient expectations diverge significantly from patients' true ex ante wishes, then the use of litigation outcomes as a marker of patient preferences may be problematic.

\footnotetext{
${ }^{32}$ Hall v. Hilbun, 466 So. 2d 856 (Miss. 1985); Clark C. Havighurst et al., Health Care Law and Policy: Readings, Notes, and Questions 1051-65 (2d ed. 1998).

${ }^{33}$ Norman F. Boyd et al., Whose Utilities for Decision Analysis? 10 Med. Decision Making 58 (1990); Paul S. Heckerling et al., Patient or Physician Preferences for Decision Analysis: The Prenatal Genetic Testing Decision, 19 Med. Decision Making 66 (1999); Melissa M. Holmes et al., Women's and Physicians' Utilities for Health Outcomes in Estrogen Replacement Therapy, 2 J. Gen. Internal Med. 178 (1987); Barbara J. McNeil et al., Fallacy of the Five-Year Survival in Lung Cancer, 299 New Engl. J. Med. 1397 (1978); Saroj Saigal et al., Differences in Preferences for Neonatal Outcomes Among Health Care Professionals, Parents, and Adolescents, 281 JAMA 1991 (1999).
} 
Two types of confounding complicate studies of legal outcomes like ours. One confounder arises at the state level. A pro-plaintiff tort environment may lead to both abandonment of the professional standard in favor of a patient one and a higher probability of plaintiff verdicts. We cannot control for the complex social, legal, and political factors that may give rise to a relatively plaintiff-friendly culture. However, their impact should be captured largely in the outcomes of other tort litigation, especially other malpractice lawsuits. We investigated this possibility by analyzing a sample of malpractice verdicts unrelated to informed consent and found no significant difference in outcomes.

The other important confounder exists at the case level. Introduction of a patient standard may change the mix of cases that proceed to trial. In theory, attorneys' response to the introduction of a more liberal standard would be to take on and press to trial some "marginal" cases that they previously would have rejected. Such changes in case mix frustrate crossjurisdictional comparisons. Our analysis mitigated the potential for systematic differences in the mix of cases across jurisdictions by controlling for the procedure-specific risk of the adverse outcome in dispute. We found that the risk levels in cases from patient standard and professional standard states were similarly distributed, and adjusting for risk had virtually no impact on the predictive power of jurisdiction type in the multivariate analysis. Thus, there was little evidence that case mix differed between the two types of jurisdictions on this important measure.

On the other hand, the risk rating was associated with case outcomes in a logical direction. The probability of a plaintiff verdict dropped steadily from 43 percent to 10 percent as the remoteness of the outcome increased from 1 in 10 to 1 in 5,000. This inverse relationship between risk level and outcome was also evident in multivariate analysis.

Although the study design was attentive to state- and case-level confounders, it has several methodological limitations. First, the sample consists of verdicts only. Because legal standards were the subject of our study, and standards emanate chiefly from court decisions and legislation, this focus was appropriate. However, only about 5-15 percent of malpractice claims are resolved by verdict. ${ }^{34}$ This raises the question of whether informed consent

\footnotetext{
${ }^{34}$ David M. Studdert et al., Claims, Errors, and Compensation Payments in Medical Malpractice Litigation, 354 New Engl. J. Med. 2024, 2026 (2006); David M. Studdert et al., The Rise of Nursing Home Litigation: Findings from a National Survey of Attorneys, 22(2) Health Aff. 219, 224 (2003).
} 
cases resolved outside of court follow the pattern we observed. There are good reasons to expect that they do. Previous research has shown that verdicts influence negotiations over claims, with settlements occurring in the "shadow" of court decisions. ${ }^{35}$

Second, jury verdict publishers do not capture every decision. Previous attempts to measure the proportion of verdicts captured have yielded estimates ranging from 75 percent to 95 percent overall, ${ }^{36}$ although the capture of personal injury cases is probably higher than other types of litigation. ${ }^{37}$ If the outcomes of unreported verdicts are significantly different from reported ones, plaintiff win rates may be biased in some states. However, it seems very unlikely that such a bias would undo the systematically different win rates we observed across the two types of jurisdiction, or that it would affect informed consent and other types of malpractice verdicts differently.

Third, the surgical reviewers' judgments about the risk of adverse outcomes did not show high interrater reliability; this variability would be expected to cause some random misclassification bias, which would skew the inverse relationship we observed between risk of the adverse outcome and the probability of plaintiff wins toward the null. Fourth, we do not measure the impact of the respective standards on the incidence of litigation. Fifth, while our findings are probably generalizable to other American states, their generalizability to legal systems abroad, where a range of other legal and social factors affect outcomes, is unknown.

In summary, our results show that moving from a professional to a patient-based standard of care in informed consent law significantly affects the outcomes of litigation, resulting in both higher standards for disclosure and greater likelihood of legal judgments against physicians for breaches of informed consent. Some will regard both these outcomes as acceptable, even desirable. Others may support the idea of a shift toward patient-oriented standards for disclosure, but balk at the increases in litigation and legal costs

\footnotetext{
${ }^{35}$ Samuel R. Gross \& Kent A. Syverud, Don't Try: Civil Jury Verdicts in a System Geared to Settlement, 44 UCLA L. Rev. 1 (1996); Thomas Metzloff, Resolving Malpractice Disputes: Imaging the Jury's Shadow, 54 Law \& Contemp. Probs. 43 (1991).

${ }^{36}$ Stephen Daniels \& Joanne Martin, Civil Juries and the Politics of Reform (1995); Mark A. Peterson \& George L. Priest, RAND, The Civil Jury: Trends in Trials and Verdicts, Cook County, Ill., 1960-1979 (1982); National Association of State Jury Verdict Publishers, supra note 20.

${ }^{37}$ National Association of State Jury Verdict Publishers, supra note 20.
} 
that this shift may entail. Regardless of the merits of the alternative standards, their coexistence exposes a tension between law and medicine: although the legal community embraces interjurisdictional differences, the medical community tends to be skeptical of geographic variation in clinical practice. $^{38}$ The presence of multiple standards may also blur the law's message to physicians regarding how they should talk to patients about treatment risks.

\footnotetext{
${ }^{38}$ Mark R. Chassin et al., Variations in the Use of Medical and Surgical Services by the Medicare Population, 314 New Engl. J. Med. 285 (1986); John E. Wennberg et al., Are Hospital Services Rationed in New Haven or Over-Utilised in Boston? 1 Lancet 1185 (1987).
} 